\title{
南アフリカ共和国における「共生」のための 教育に関する一考察
}

一西ヶープ州の高等学校を舞台とした認識のせめぎ合いに着目して—

坂口 真康

(筑波大学大学院学生/日本学術振興会特別研究員)

\section{はじめに}

本稿の目的は、アパルトヘイト (人種隔離政策) 崩壊後の南アフリカ共和国 (以下、南ア) に抢ける「共生」のための教育について、西ケープ州の高等学校 を舞台とした認識のせめぎ合いに着目した考察を行うことである。その背後に は、南アの「共生」の実践と日本の議論を比較——異なる文脈の実践をもとに 理論を可視化一一することを通じて、「共生」論の精緻化を図るという狙いが ある。

昨今、人々の価値観の多様化に伴い、「共生」(または「共生社会」）概念が注 目を浴び、これまでに様々な取り組みが行われてきた。現在、頻繁に用いられ る「共生」概念であるが、当初は「差別の克服のために諸個人の権利を擁護し 差異を承認させるためのもの」(岡本 2013: 120)であったとされる。それが 1990 年代半ば以降に政策的議論で採用され、個人のみではなく社会からの要請が加 えられるようになり、「社会のなかの多様性」の尊重と「社会の凝集性」の実 現を同時に果たそうとする概念」(同上書: 120) となってきたことが指摘されて いる。

そのような中、「共生」概念については、その言葉が持つ「美しさ」ゆえに 覆い隠されてきた状況が存在することが批判され、そのような状況を打破する ために、現在までに様々な議論が展開されてきた。そして、そのような議論に おいて中核を担ってきたのが、「共生」を状態ではなくプロセスとして捉える 議論である。 
野口道彦は、「不平等な構造を一時的に凍結しただけの共存であれば、真の 共生」とは言えず、「共生」とは、「それに向かって絶えず求めていくべきプロ セスであって、「われわれは共生している。何も問題はない」と言ったとたん に、欺瞞的な言説」(野口 2003: 29) になると述べ、「「共生」は達成されたもの ではなく、達成を目指して不断に努力すべきもの」（同上論文: 30）であるとし ている。「共生」がプロセス概念であるという点は、「多様性の尊重」という概 念的特徴とも関わってくることである。多様性を前提としている時点で、新た な他者との出会いが常に想定され、出会いが生じる度に、新たな「共生」の営 みが開始されるのである。

そして、他者の差異を受容し続けることにより起こりうるものと想定されて いるのが、「せめぎあう共生」(斎藤 1988) とも言われる自他の差異が引き金と なる対立である。「共生」がせめぎ合いを含むという点については、「みんな仲 良く生きる」といった「調和」や「協調」のイメージが付与された（井上ほか 1992: 24)、いわゆる「美しい」状態としての「共生」に打いては、否定的な ものとして捉えられてきた。しかし、井上達夫ほかが、そのような「共棲」と しての「共生」を否定し、「異質なものに開かれた社会的結合様式」(同上論文: 25）としての開かれた「共生 (conviviality)」では、「ハーモニーよりは、不協和 音の雑然たる喧噪の方が常に大きい」(同上論文: 26) と述べるょうに、差異を 前提とした「共生」では、「美しくない」側面の割合が大きいことが指摘され てきた。これらの議論からは、他者の存在が常に想定されるプロセスとしての 「共生」には、差異が引き金となるせめぎ合いが生来的に含まれており、それ が「共生」を試行する際の前提となっていると解釈できる。この点において 「共生」は、「口当たりのよいもの」ではなく「苦さ」を含む (野口 2003: 27) も のであり、しばしば流行語としての「共生」に付与される「美しい」イメージ とは異なるのである。

以上に示したと抢り、「共生」概念については、意味が厳密に考えられるこ となく流布していることが批判され、その精緻化のための議論が各方面で行わ れてきた。とはいうものの、調査が困難であったことなどを理由にこれまで十 分に取り上げられてこなかった文脈も存在する。本稿では、そのような文脈の 一つである南アに着目する。峯陽一によると、南アの政治や経済には多くの固 
有性があるが、それを「「特殊なケース」として分析することは、もはや適切 ではなくなって」おり、世界中で見られる問題を抱える南アを「「世界の縮 図」ととらえる視点は、私たちに貴重な比較研究の展望を与えてくれる」(峯 1998: 57）とされる。そのような指摘がなされる中で、教育という分野におけ る現在の南アの「共生」の取り組みをもとに、既存の「共生」論を考察する点 に本稿の意義がある。

なお、本稿では、上述したように「共生」を巡る議論において一つの論点と され、これまでにも実践をもとにした分析が行われてきた（e.g. 羽田野 2011）、 「共生」におけるせ女ぎ合い——その中でも特に認識のせめぎ合い——が、南 アではどう現われ、どう対処されているのかに焦点を当てた分析を行うことと する。

\section{1. ポスト・アパルトヘイト時代の南アにおける「共生」のための教育}

1994年に初めて民主的選挙が行われ、制度としてのアパルトヘイトが撤廃 された南アでは、新たな体制のもとで過去の被害者と加害者が「どのように共 生 [live together] できるか」(Moodley 2004: 1034) が課題となり、「南ア憲法」の 制定や真実和解委員会 ${ }^{(1)}$ の活動など、これまでに様々な取り組みが行われてき た。

そのような活動に呼応する形で、現在の南アでは、多くの人々がアパルトへ イトに否定的な見解を抱いている様子がうかがえる。例えば、正義和解協会 ${ }^{(2)}$ が 2012 年に行った調査 ${ }^{(3)}$ では、調査対象者の $83.8 \%$ が「アパルトヘイトは人道 に対する犯罪であった」と考えているという結果が示された (Lefko-Everett 2012: 37 )。

しかし一方で、「南ア憲法」の「崇高な理念をうたいあげている」(山本 1999: 286）とされる憲法の前文の「南アフリカがそこに住むすべての人々のも のであり、多様性のなかで統合されることを信じる」(同上書: 286) といった文 言とは裏腹に、現実の南アにおいては、その理念の実現の難しさが浮き彫りに なっている側面がある。それを顕著に示すものとして、例えば、前述した正義 和解協会の調査結果が挙げられる。本調査では、「もっと他者のしきたりや慣 
習について学びたい」と答えたのは $38.8 \%$ 、「他の人種の人々ともつと頻繁に 話したい」と答えたのは $23.2 \%$ という結果が示され、自分の家などで他の「人 種」の人々とほとんどまたは全く交際しないと答えたのは $56.6 \%$ ああるという 結果が示された (Lefko-Everett 2012: 43-44)。本調査結果からは、現在の南アで は「南ア憲法」で謳われたような「多様性の中で統合」された状況にはなりき れていない様子がうかがえる。

とはいうものの、南アのそのような状況を打破するための取り組みが全くな されてこなかったわけではない。前述した憲法の制定や真実和解委員会の活動 以外にも様々な活動が展開されてきたが、南アの過去と未来に向き合う中でも、 特に重要なものの一つとされてきたのが教育制度改革である (Volmink 2008: 190)。

1994年以降、南アでは抜本的な教育制度改革が行われてきたが、例えば、 2000年代前半に、ネルソン・マンデラ政権下に制定されたカリキュラムの見 直しと改訂が行われたことは、南アの「共生」のための教育を語る上で重要な 出来事であった。なぜなら、カリキュラムの改定 (DoE 2002; DoE 2003) ${ }^{(4)}$ によ り、南アの新しい教育制度の設立において最も成功した取り組みの一つ (Prinsloo 2007: 169) ${ }^{(5)}$ とされるLife Orientation という名の科目が設立されたか らである。本科目の設立により、それまでに南アで十分に扱われてきたかどう かに疑問が残る (山田 2005: 82) とされていたシティズンシップや人権に関する 教育を営む科目が、必修科目として設置されたのである ${ }^{(6)}$ 。本科目が設置され たという経緯からは、学校で「共生」のための教育をより体系的に行うという 方向性が示されたといえる。

ナショナル・カリキュラムによると、高等学校段階のLife Orientation では、 自己、他者や社会に関する知識、価值観、態度やスキルといった多面的な観点 からアプローチすることにより、学習者に彼/彼女たちの憲法上の権利や責任 を行使する方法、他者の権利を尊重する方法、多様性、健康やウェル・ビーイ ングを尊重する方法を知ることが可能となる機会が提供されているとされる (DoE 2003: 44-45)。「多様性の中での統合」(Bentley \& Habib 2008: 5) を理念に 揭げたとされる「南ア憲法」の体現を目指すLife Orientationは、前述した「共 生」論との親和性が見られることからも、現在の南アにおいて「共生」のため 
の教育の一翼を担っていると捉えることができる。本稿はあくまでも学校教育 全体の「共生」を分析するものであるが、この点を踏まえて、後述する調査の 分析では、Life Orientationの教員の語りや授業を巡る学習者の語りに着目する こととする ${ }^{(7)}$ 。

\section{2. 調査の概要}

本稿では、2012年の 7 月と 8 月および2013年 7 月に、南ア西ケープ州の高等 学校3校にて教育者と学習者を対象に実施したインタヴュー調査で得られた データの一部を分析する。インタヴュー調査では、「共生社会」はどのように 教育／学習されているのかについて明らかにすることなどを目的として、「「共 生社会」をどのようにイメージしますか」や「「共生社会」[実現]のための鍵／ 障壁は何だと考えますか」などの質問について尋ねた（英語による半構造化面 接法で実施)。

調査地に西ケープ州を選択したのは、「人種」的多様性を有している ${ }^{(8)}$ 、教

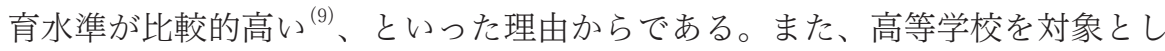
たのは、アパルトヘイト崩壊後に生まれた世代である学習者の教育／学習に着 目することで、現在の南アにおける「共生」のための教育の特徵をより的確に 捉えることができると考えたためである。なお、調査対象校 3 校に共通した特 徵としては、(1)公立学校である、(2)高等学校修了資格試験の合格率が比較的高 い、(3)施設・設備が比較的整っている、といった点が挙げられる。また、各校 の基本情報は、以下のとおりである（基本情報は、学校や個人が特定されない 形で提示するように留意した（後述するインタヴュー対象者の基本情報も同 様))。

学校 A は、10年生から 12 年生までの学習者数が500名に満たない比較的小 規模な学校である。学校 B は、10年生から 12 年生までの学習者数が500名から 600 名程度の中規模な学校である。学校 C は、10年生から 12 年生までの学習者 数が 600 名以上の比較的大規模な学校である。本稿では、認識のせめぎ合いに 関する分析を行うために、調査結果の分析においては、調査に協力していただ いた 3 校の、学習者計 63 名 (そのうち、11年生と 12 年生の学習者計 50 名)、 


\begin{tabular}{|c|c|c|c|c|c|c|}
\hline \multicolumn{4}{|c|}{ 教育者 } & \multicolumn{3}{|c|}{ 学習者 } \\
\hline 仮名 & 役職／主な担当科目 & 教職歴 & 実施日 & ID & 学年 & 実施日 \\
\hline E氏 & 副校長 & 30 年以上 & 2012年7月 & 9 & 11 年生 & 2012年 7月 \\
\hline F氏 & Life Orientation 主任 & 20 年以上 30 年未満 & 2012年 7月 & 17 & 11 年生 & 2012年 7月 \\
\hline H氏 & 副校長 & 30 年以上 & 2012年 8 月 & 18 & 12年生 & 2012年 7月 \\
\hline I氏 & Life Orientation 主任 & 20 年以上 30 年未満 & 2012年 8 月 & 22 & 12 年生 & 2012年 8 月 \\
\hline J氏 & Life Orientation & 10 年未満 & 2012年 8 月 & 25 & 12 年生 & 2012年 8 月 \\
\hline K氏 & 校長 & 30 年以上 & 2013年 7月 & 32 & 12 年生 & 2012年 8 月 \\
\hline \multirow{2}{*}{ L氏 } & \multirow{2}{*}{ 副校長 } & \multirow{2}{*}{20 年以上 30 年未満 } & \multirow{2}{*}{2012 年 8 月 } & 38 & 12 年生 & 2012年 8 月 \\
\hline & & & & 39 & 12 年生 & 2012 年 8 月 \\
\hline \multirow{2}{*}{ Q氏 } & \multirow{2}{*}{ Life Orientation 主任 } & \multirow{2}{*}{20 年以上 30 年未満 } & \multirow{2}{*}{2012 年 8 月 } & 51 & 12 年生 & 2012年 8 月 \\
\hline & & & & 54 & 11 年生 & 2012年 8 月 \\
\hline
\end{tabular}

Life Orientation の教員計8名、管理職者計8名のうち、「共生」を巡る認識のせ めぎ合いや、その対処のされ方として捉えることのできる象徵的な語りが得ら れた調査対象者に焦点を当てた分析を行う（本稿で取り上げる調査対象者の基 本情報は表 1 を参照)。

なお本稿では、「差別を温存した上での共生はありえ [ない]」(野口 2003: 29 一一括弧内引用者）とする議論に依拠した上で、南アの文脈に沿った分析を行 うために、「人種差別」の話題を中心的に取り扱う。具体的には、「人種」カテ ゴリや「差別」に対する認識間のせめぎ合いについて分析し、せめぎ合いの対 処のされ方について分析した上で、南アの「共生」のための教育の特徵を考察 する。

\section{3.「人種」カテゴリと「差別」を巡る認識のせめぎ合い}

\section{（1）積極的差別是正措置と「人種」カテゴリを巡る認識のせめぎ合い}

はじめに、過去の「人種差別」を克服するための取り組みであるアファーマ ティヴ・アクション (積極的差別是正措置) と「人種」カテゴリを巡る認識の せ女ぎ合いについて分析する。そのような分析を行うのは、自他の差異が前提 とされるプロセスとしての「共生」論において一つの論点とされてきた、自他 を隔てる社会的カテゴリ (e.g. 岡本 2013) の立ち現われ方と取り扱われ方につ 
いて、具体的場面をもとに可視化するためである。

南アでは、過去の負の遺産を緩和するために、「南ア憲法」により積極的差 別是正措置の実施が認められている（大津 2000: 108）。しかし、インタヴュー 調査からは、本措置に対する認識は一筋縄ではいかない様子がうかがえた。例 えば、校長 K氏は、南アで「人種差別」は未だに大きい問題だと考えるかとい う質問への回答の中で、「とても大きな問題である」と語った後に、積極的差 別是正措置により「人種の優越性が強化されている」として、次のように述べ ている。

そうですね…つまり、人種差別は存在するということです。なぜなら、 もし私が…もし私が白人として職に応募していたとして‥あるいは誰か… 職に応募している誰かだとして、その職を黒人性あるいはカラード性とい うカテゴリによって得たとしましょう。すると、職を得なかった人は $[\cdots]$ 相手にこだわりを持つことになるでしょう。しかもそれは $[\cdots]$ 人間 としてではなく、特定の人種集団に属する人というこだわりとなるでしょ う。そしてそのような憎しみは続くことになるでしょう。そしていつか爆 発するでしょう。この問題に関して私たちは時限爆弾の上に座っているの です (K氏 $)^{(10)}$ 。

この語りからは、積極的差別是正措置は「人種差別」であるという見解が示 され、「人種」が強調されることに対する懸念が表明されている様子がうかが える。

ところが、K氏のような認識がある一方で、負の遺産の是正という観点から、 積極的差別是正措置を全面的には否定しない語りも得られた。例えば、別の学 校の副校長E氏は、本措置をどう考えるかという質問に対して、「悪いもので はありません」とした上で、長い間持続できないことから手放しで賛成しない ものの、現在必要とされていることから全面的に否定しない様子がうかがえた。 同様に、Life Orientationの主任F氏からは、大学申請書類の「人種」欄に関す る話題の中で、「不公平」だと感じるが、南アの人口構成を考えると仕方がな いといった語りが得られた。これらの語りからは、積極的差別是正措置に全面 
的には賛成しないものの、過去の負の遺産の是正や南アの現実という観点から、 現在の南アにおいて、本措置の実施はやむを得ないとする認識が抱かれている 様子がうかがえる。このように、「人種」カテゴリによる措置を暫定的に認め るという E氏と F氏の語りからは、両氏が校長 K氏とは異なる認識を抱いてい る様子一一認識のせめぎ合いが存在すること一一が指摘できる ${ }^{(11)}$ 。

「人種」カテゴリをもとに営まれる積極的差別是正措置に対して否定的な立 場をとり、大学申請時等には、「人種」を記入させないようにする教育を営ん

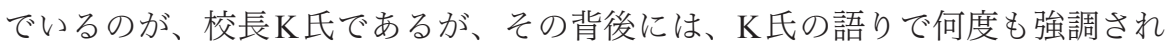
た「人種」ではなく「人間」という見方を重視する姿勢があると言える。とは いうものの、そのような見方を重視するK氏自身の中にも、「人種」を巡る認 識のせ女ぎ合いがあることを指摘することができる。例えば、南アでは「共生 社会」が形成されておらず、政府は制度改革を行う必要があるという K氏の見 解について、その意図を再度尋ねた質問に対して、K氏からは、「土地の話を した途端に白人は取り乱すのです」という語りの後に、「白人」を「彼／彼女 たち」と呼ぶ語りが得られた。この語りからは、K氏が「白人」カテゴリに属 する人々を自分とは異なる存在として認識している様子がうかがえる。つまり、 「人間」という見方を強調しながらも、特定の「人種」として他者を認識する ことから抜け出せていない——人種」カテゴリを巡る認識のせめぎ合いを抱 えている——様子がうかがえるのである。

ただし、このような「人種」を巡る認識のせめぎ合いについては、K氏自身 も自覚していることである。そのことは、「人間」という見方を強調しても 「人種」で話をする人が現実にはいる中で、そのような人にどのように対応す るかという質問に対して、K氏が、「人間」という見方を強調しても、過去に ついて話をするときは、「いわゆる」という言葉を付けながらも、「人種」の話 をしなければならないと発言していることからもうかがうことができる。K氏 も認めているとおり、南アでは過去の負の遺産について言及する際には、否応 なしにでも一賛成しなくとも—、「人種」カテゴリを使わざるを得ない場 面が生じるのである。

そして、そのような場面の一つとして挙げられるのが、Life Orientationの授 業である。以下に示したのは、Life OrientationでもK氏が主張する「人種」観 
に沿った話がされているのかという質問に対するK氏が校長を務める学校に通 う学習者の回答である。

いいえ。私は…私は、それら［Life Orientationの授業］において、彼［校 長K氏）と同じメッセージが発せられているとは思いません。なぜなら、 つまり… Life Orientationでは、彼/彼女 [教員］たちは教えなければなり ません．彼/彼女たちは私たちに、実際に起きたことを教えます。 $[\cdots]$ 「黒人、白人、カラードがいます」といった発言をします。でも、彼 [校 長 K氏]はそのようなことを信じていません。[調査者：なるほど。］だから、 両者は、いつも同じメッセージを発しているわけではありません（学習者 ID39)。

この語りからは、Life Orientationにおいて過去の話をする際には、必然的に 「人種」カテゴリの話をしなければならず、「人間」という見方のみで他者を認 識することが困難な様子がうかがえる。このことは、Life Orientationの授業だ けに留まらず、社会において「人種」が多分に使われている（学習者ID32）こ とや、実際に学習者の間でも「人種差別」が起こることから、「人種」による

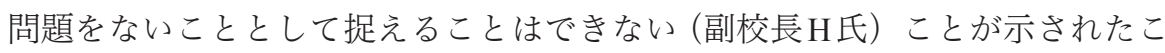
ととも関連している。

これらのことからは、どれだけ「人種」カテゴリから逃れようとしても、ア パルトヘイトを経験した南アにおいては、「人種」を使わざるを得ない場面が あり、それが「人種」カテゴリを巡る認識のせめぎ合いを生み出していると解 釈できる。

\section{（2）「差別」を巡る認識のせめぎ合い}

以上に示したのは、「人種」カテゴリに対する認識のせめぎ合いであった。 次に、「差別」そのものに対する認識のせめぎ合いについて分析する。そのよ うな分析を行うのは、前述した野口 (2003) の議論に見られるように、差別を 残したままの「共生」はありえないとされてきた中で、現在の南アにおいて、 「差別」(特に「人種差別」) はどのように認識されているのかについて可視化す 
るためである。

野口（同上論文）の議論を後支えするように、本稿で取り上げた学校におい ても、「人種差別」を許容しない様子をうかがうことができた。例えば、南ア において未だに他の「人種」集団に対して偏見を示す人々がいるという話題に 関するやりとりの中で、副校長 L氏からは、学校で特定の「人種」を見下す学 習者が現れた場合、「厳格に」「ただちに」対処するという語りが得られた。同 様に別の学校の副校長E氏からは、学校で最近「人種差別」を見かけたかとい う質問に対して、他の「人種」集団を侮辱する言葉が使われたという出来事が あったが、学校としては、人権問題を扱う専門の機関に報告し、専門のカウン セラーを呼び、全校を対象とした反「人種差別」のプログラムを実施したとい う語りが得られた。

ところが、「人種差別」には、一筋縄ではいかない側面もあることが指摘で きる。例えば、学校で「差別」的な振る舞いをする人を見かけるかという質問 に対して、「ひどく人種差別的」なことは、「トラブル」のもとになるため言わ ないが、お互いが「呪談」で「真剣ではない」と分かっているとき、もし誤解 が生じたときには訂正できると考えられるとき、「攵談」を言い合って「遊 ぶ」ことがあるという語りが得られた（学習者ID38）。また、学校において 「人種差別」を見かけるかという質問に対するやりとりの中で、自身の特徵的 な方言について「談」として真似されることがあるが、やめてほしいときに はやめてもらえることや、みんなそれぞれが異なる方言を持っていることから 気にしていないといった語りの後に、「人種差別的」な「呪談」は、むしろお 互いの関係性が近くなったからこそできるようになったという語りが得られた (学習者ID17)。同様に、「差別」は「共生社会」の障壁か一部かという質問に 対して、以下のような語りが得られた。

それ [「差別」] は障壁となります。なぜなら…もしあなたが差別をすれ ば $[\cdots]$ いったいどのように他の人々と一緒に生きるのでしょうか。 $[\cdots]$ でも、見方によれば、たぶんそれは強みにもなり、あなたは学ぶことがで きるのです… [調査者：なるほど。]他の人々も彼／彼女たち自身をよりよ くしたりできます。だから、それには長所と短所があるのです (学習者 
ID22)。

これらの語りからは、「差別」は「共生」の障壁ではあるが、「差別」から学 び、改善することができるという「強み」もあるという認識が読み取れる。こ れまでの「共生」に関する議論でも指摘されてきた、せめぎ合いが「共生」の 契機となりうるという側面 (e.g. 羽田野 2011) が、本稿の調査でも確認された のである。

とはいうものの、学習者間で「呪談」の「人種差別」が全面的に許容されて いるわけではない。例えば、ある学習者は、学校において身の周りで「差別的 な振る舞い」をしている人々を見かけるかという質問に対して、特定の「人 種」が別の「人種」集団を深刻なやり方ではなく「攵談」として「からかう」 ことを見かけるが、人の気持ちを傷つけていることや、「圥談」でも学校が厳 格に対処している「いじめ」となりうるという懸念を表明している（学習者 ID25)。

以上の語りからは、学校での「差別」には、深刻でない場合、「呪談」とし てお互いを知る契機として認識される側面と、いかなる形でも許容されるべき ではないと認識される側面——なわち認識のせめぎ合い——゙あることが指 摘できる。

\section{4. 認識のせめぎ合いの対処のされ方}

上述した語りからは、「人種」カテゴリに対する認識や「差別」そのものに 対する認識間のせめぎ合いが見受けられた。ここでは以下、そのような認識の せめぎ合いが、どのように対処されようとしているのかについて分析する。

\section{（1）思考の相違を前提とした上でせめぎ合いを受け入れるという対処のされ方}

はじめに、認識のせめぎ合いを生み出す自他の思考を変容させることは困難 であると認めた上で、せめぎ合いをそのまま受け入れるという対処のされ方を 指摘する。例えば、Life Orientation主任のQ氏は、学習者が親の世代からの影 響を受けていることについての見解を尋ねた質問の中で、親の思考から影響を 
受けていると、学習者の思考を変容させることは非常に困難であるという認識 を表明している。同様に別の学校のLife Orientation教員のJ氏からは、学習者 が他者を尊重し、他者に寛容になるために必要な態度は何か、という質問に対 して、教育した内容をどうするかは個人的なことであり、教員が学習者に何か を強制することはできず、学習者の選択に委ねるしかないという認識を抱いて いる様子がうかがえた。またこれらの教員と同じく、学習者からも、教員は学 習者に「正しい道」を示すが、学習者を強制的にそこに向かわせることはでき ないという語りが得られた(学習者ID9)。これらの語りからは、他者の思考を 変容させることは困難であるという前提のもとで、教育と学習が営まれている 様子がうかがえる。

そして、このような他者の思考を変容させることに否定的な認識は、「差別 的な振る舞い」をする人々についても当てはまるとされている様子を指摘する ことができる。以下に示したのは、Life Orientationでは「差別」の問題が取り 上げられているかという質問に対して、授業がそのような話題になった際には 「人種差別」や信条について議論することがあると答えた後に、自分の身の周 りで「差別」を見かけた際にはそれは間違っていると伝えると表明した学習者 の語りである。

でも…基本的には、私はそのような [差別に関する]話題を自ら人に投 げかけるようなことはしません。なぜなら、私は他の人の信条や人種に何 か問題があるとは考えていないからです(学習者ID51)。

この語りからは、表面化した「差別」は間違いであるため対処するとしなが らも、表面化していない限りは、他者がいかなる信条を持つことをも受け入れ ている—他者の思考を変容させることは想定していない一様子がうかがえ る。

それでは、他者の思考を変容させることの困難さを前提とした上で、認識の せめぎ合いは、実際の教育場面に拈いて、ぞのように対処されようとしている のか。例えば、Life Orientation主任のQ⿱氏丶犬、「多様性」を教授する際に、何 を強調するかという質問に対して、個々人への「尊重」が重要な要素となると 
答えた後に、以下のように述べている。

私たち全員が同じ意見を持っていないかも知れません。しかし、私たち は人々が異なる意見を持っているということを認める必要があります。し かし…私たちはそれらの意見を尊重する必要があるのです。同意しないか も知れませんし、承諾しないかも知れません。それでも…特定の問題をみ んなが同じ立場に立って考えているわけではないということを認めるので す。それはつまり、誰が正しくて誰が間違っていると言うのではなくてで す。そのことを理解することが重要だと私は考えます（Q氏）。

ここでの語りからは、他者の思考は変えられないという前提のもと、認識の せめぎ合いを無理に合意にいたらせるのではなく、せめぎ合いをせめぎ合いと して認識することを重視した教育が営まれている様子がうかがえる。教育資源 としての「共生」概念の可能性を考える際には、「ある者と別の者との認識の 対立があったときに、片方がもう片方を凌駕しょうとするのではなく、対立し ている認識の枠組みがいかなるものであるかを、両者が対象化し理解すること の効用を、主張することになる」(岡本 2013: ii) とされてきたが、そのような 「共生」論に呼応する形で、本稿で取り上げた語りからは、認識のせめぎ合い を解決できない際には、差異をそのまま受け入れるという選択肢がとられてい る様子が確認できる。

\section{（2）せめぎ合いが表面化したことによる被害を前提とした対処のされ方}

以上の語りからは、「差別」はよくないものであるという認識がされながら も、他者の思考変容は困難である、またはいかなる思考であっても尊重される 必要がある、という前提のもとで、認識のせめぎ合いは存在するということを 認めるための教育がなされている様子がうかがえた。そのような認識のせめぎ 合いが前提とされた際に問題となるのが、せめぎ合いが暴力的に表面化した際 の対処法である。次に、その際の対処法の一つとして、認識のせめぎ合いが表 面化したことによる被害に影響を受けないための教育が営まれている様子を指 摘する。 
例えば、Life Orientation主任のI氏は、身の周りにいる「差別」的な人々か ら思考が影響を受けないようにすることが大切であるという話題の中で、「被 害者」は出てしまうものであるが、「被害者」が自分を責め続け、「被害者」と して留まることなく、前進することが重要であるという見解を示した。そして、 Life Orientationの授業に関する話題の中で、I氏は以下のように述べている。

調査者：あなたが述べてきたように、Life Orientationは人生について取り 扱っていますが、実際に生徒も、それが彼／彼女たち自身、彼／ 彼女たちの人生、そして彼／彼女たちの人生をどのように過ごす かに関するものであると感じていますよね。

I 氏：どのように‥どのように対処し、どのように生き延びるのか。自 分に何かが起こったときにどうするのかについてです。

ここで示した、Life Orientationでは、何かが起きたときにどのように対処す るか、どのように「生き延びる」かについて教えているという語りからは、I 氏が人生において困難は起こりうるという前提のもとで教育を営んでいる様子 がうかがえる。すなわち、現在の南アにおいては、アパルトへイトの負の遺産 による「人種差別」はすぐにはなくならず、常に起こりうるものであるという 認識のもとで、そのような社会をいかに「生き延びるか」ということに焦点を 当てた中で、「共生」のための教育が営まれている側面があるのである。

\section{5.「共生社会」に対する理想と現実の違いを踏まえた上での教育}

「南ア憲法」においては「人種差別」を認めないという理念が詔われている が、そのような理念どおりの現実が見られないのが、現在の南アである。言う までもなく、Life Orientationをはじめとした学校教育においては、反「人種差 別」の重要性について取り扱われるが、本稿の分析結果からは、それと同時に、 そのようにはならないのも人間社会であるという側面も扱われている様子がう かがえた。

とはいうものの、本稿で取り上げた調査対象者が「共生社会」について全く 
希望を付与していないわけではない。本稿で取り上げた調査対象者からは、 「共生社会」という言葉を聞いてどのようなことをイメージするかといった質 問に対して、肯定的なイメージが表明されたのである。例えば、教育者の間で は、「違いに関係なく調和のとれた社会」(Life Orientation主任I氏) や、「異種多 様な人々を協力させること」(Life Orientation主任Q氏）といった、イメージが 語られた。同様に、学習者からは、「みんなが争うことなく、平和と調和のう ちに生きること」(学習者ID9)や、「みんなが社会とコミュニティにおいて平等 であり、互いにうまく関わり、対立がないこと」(学習者ID32)といったイメー ジが語られた。このように、「共生社会」という言葉自体に対しては、「平和」 や「調和」などの「美しい」イメージが付与されていることが指摘できる。し かし前述したとおり、本稿で取り上げた調査対象者は、南アの現実に対して、 そのような「美しい」側面だけを期待しているわけではない。その点から、彼 ノ彼女たちは、「共生社会」をイメージすることと、実際に社会で他者と「共 生」することを切り分けていると解釈できる。すなわち、理想と現実の違いを 受けとめた上で、アパルトへイトの負の遺産が残る社会で、いかに現実的に他 者と「共生」するのかということを模索し、試行しているのである。

以上に示した理想と現実を切り離し「共生」を試行する様子は、南アで「共 生社会」が達成されていると考えるかという質問に、現在は達成されていない が将来達成されることを望むと答えた後に得られた、以下の語りに凝縮されて いる。

私たちは、今なお、私たちの国の和解のプロセスにあると考えています。 […ㄱれ［南ア］はとても若い民主主義なのです。だから私たちは今なお 成長しているのです。枑い現実的に交流できるようになるために学んで いるのです。 $[\cdots]$ そのようなプロセスを…私たちが達成できるようになる ためには、長い時間がかかるのです (学習者IDl8)。

教育と並んでポスト・アパルトヘイト時代に重要な役割を担ってきたとされ る真実和解委員会 (Volmink 2008: 190) 後の南アにおいて、人々はアパルトヘイ ト下の出来事に関する「和解」に明確な終わりがないことを認識し、日々の生 
活の中で「共に生きる（live together）」ことを学ぶことが現実だということに 気づいた（Tihanyi \& Du Toit 2005: 26）とされてきたが、本稿の分析結果からは、 そのような営みが現在の高等学校においても行われていることが確認できる。

\section{おわりに}

1993年の「暫定憲法」の完成から1994年に初の民主的選挙が実施されるまで、 南アは「内戦寸前の状態」(トンプソン 2009: 445) にあり、当時の大統領である フレデリック・デクラークと後に新生南ア初代大統領となるネルソン・マンデ ラは、「白人の間にも黒人の間にもいる過激主義者が内戦を招き、救うべき祖 国を破壊しょうとするのを憂えて」「アパルトヘイトから民主主義と人種平等へ 平和的に移行する道を発見するために粘り強く働いた」(ローレン 1995: 412) と される。そのような「内戦」の危機を乗り越えながらも、現在の南アでは、過 去の被害者と加害者を含み込んだ上で「共生」する道が選ばれたのである。そ の点において、南アの「共生」にはその営みを始める時点ですでにせめぎ合い が含み込まれていたことになる。そのような中、「内戦」の危機をぎりぎりの 所でかわしてきた南アでは、本稿の語りに見られたように、認識のせ女ぎ合い を認めた上で、それらが表面化した際にいかに対処するかという中で、「共 生」が試行されている側面があるのである。そして、自他の差異が前提とされ た中、学校教育では、認識のせめぎ合いにより「差別」は起こりうることを前 提とした取り組みが行われているのである。このことからは、現在の南アの 「共に生きる」ための教育とは、— Life Orientation主任I氏の「生き延びる」 ための教育を営んでいるという語りに見られたように一一「共に生き延びる」 ための営みという側面も有していると捉えることができる。多様性を尊重する とは、それだけ切羽詰まった中で営まれるものなのである。

とはいうものの、「多様性の尊重」による認識のせめぎ合いが前面に押し出 されてしまうと、「共生」のもう一つの軸である「社会の凝集性」が危ぶまれ る。そのような中、南アでは、人々が過去から受ける影響は多様ではあるが、 誰もが過去の影響を受けているという認識が共有されているという点において、 「社会の凝集性」が保たれようとしていると解釈できる——過去は人々を団 
結させることもある」(学習者ID54)といった語りからもそのことがうかがえる。 「共同体の悲劇の後には、犠牲者の間で連帯感が強まり、気持ちがつながるこ ともある」(シリュルニク 2014: 207) とされるが、現在の南アでは、内実は多様 ではあるが、アパルトへイトという記憶の共有により、「社会の凝集性」が確 保されようとしているのである。

「同化」の原理と対立する「共生」においては、「どのような違いを認め合う のかという点が問題」(野口 2003: 32) になるとされてきたが、本稿の分析から は、いかなる認識の違いをも認めるのが、南アの「共生」の一形態であること が示唆された。ただし、あらゆる認識が表出されていては、「共生」を営むこ とができない。そのような中、本稿で見えてきたのは、「差別」的な認識で あってもそれが内面に留まる限りは個人の信条としてその存在を認めるが、自 他を生命の危険にさらす振る舞いとして外面に表出されることは許容しないと いう形態の「共生」であった。最後に、南アのそのような形態の「共生」を可 能にしていると思われる思想の一つを提示して本稿を締めくくる。

その思想とは、人間の「失敗」を前提とした思想である。それは、現在の南 アに㧫いて「共生社会」は見られるかという質問に対して、今はまだ特定の価 值観や思考を持った人々がいるため、「共生」には時間がかかるとした後の 「私たちはみんな人間です。つまり、私たちはすべて完璧ではないということ です」(Life Orientation教員 J氏）と答えた教員の語りにも象徵される（真実和解 委員会で強調された「赦し」という発想にもそのような「失敗」を前提とした 思想との親和性が見られる)。「美しい」お題としての「共生」では懸念事項と されるであろう人間の「失敗」を前提とすることで、多様性を尊重する道も開 かれうるであろうし、人間の「失敗」を共にやり直すことにより、過去を共通 の土台として一つのまとまりを築く道も開かれうると思われる。アパルトへイ トを経験しながらも、被害者も加害者も含み込む選択肢をとった多文化社会南 アの「共生」の実践からは、「多様性の尊重」と「社会の凝集性」に同時に取 り組む際の前提として、人間の「失敗」を認めるという点を「共生」論に還元 することができる。この点を踏まえると、今後は、「共生」と「失敗」の許容 の関連について、より詳細に検討することが課題となる。 


\section{【注】}

（1） 1996年から 1998年に設置された、アパルトヘイト下に起きた事件の真相を明らかにし、 「被害者の救済を考え、また、加害者には恩赦を与えることで国民和解を達成する」(山本 1999: 217)ことを目的としたとされる委員会である。

（2）本協会は2000年に発足した非政府組織であり、本協会の調査は、南アの「和解」の進渉 を縦断的に測る唯一の調査であるとされる(Lefko-Everett 2012)。

（3）本調査は、南アの9つすべての州で3,565名(15-34歳：1,735名、35歳以上：1,830名)を対 象に実施された質問紙調査である (ibid.: 11, 13)。

（4） 2012 年には再び新カリキュラムが導入され、「カリキュラムとアセスメント方針の提 言」が各科目に通達された (e.g. DoBE 2011)。ただし、高等学校では2012年から 3 年にわた り段階的に新カリキュラムが導入されたため、本稿で語りを取り上げる学習者(インタヴュ 一調査を実施した 2012 年時点で 11 年生と 12 年生) は、「カリキュラムとアセスメント方針の 提言」以前の授業を受けた世代である点に留意する必要がある (同様に、本稿で取り上げる 教育者を対象としたインタヴュー調査も、新カリキュラムへの完全移行以前の 2012 年と 2013年に実施したものである点に留意する必要がある)。

（5）そのような指摘は、Life Orientationが、責任感、充足感や幸福感を抱いた職業人、市民、 家族の一員や神聖な個人として成熟するために必要な事柄をすべて含んでいる (Prinsloo 2007: 169)という見解のもとでなされている。

（6）南アの高等学校段階の130単位の内、70単位が4つの基礎科目 (必修科目)で占められてい るが、Life Orientationには 10 単位が当てられ、言語と数学系の科目には、それぞれ20単位 が当てられている (DoE 2003: 21)。他科目を差し置いて、必修科目として週に2 時限設置さ れていることからは、南アの学校教育の中で、Life Orientationが重要な位置を占めているこ とがうかがえる。

（7）高等学校におけるLife Orientationに関する先行研究 (e.g. Prinsloo 2007; Van Deventer 2009)では、教育者の視点から、言語的多様性による教授/学習の困難や教員研修の問題点 などは指摘されてきたが、学習者の視点も含み込んだ上で、「共生」という観点からの詳細 な分析は管見の限りされてこなかった。

（8） 2011 年の国勢調査によると、西ケープ州は南アの全州の中でも、「カラード」 $(48.8 \%) 、$ 「白人」 $(15.7 \%)$ とその他」 $(1.6 \%$ ：北ケープ州と同率 $)$ の割合が最も高く、「インド人/ア ジア人」 $(1.0 \%)$ の割合が 3 番目に高く、「黒人/アフリカ人」 $(32.9 \%)$ の割合が最も低いとさ れる (Statistics South Africa 2012: 17)。

(9) 例えば、2011年の国勢調査によると、西ケープ州では、15歳以上で教育を受けていない、 あるいは 7 年生と同等以下の教育しか受けていない人たちの割合が $12.6 \%$ (南ア全体の平均 は 19.1\%)であり、全州の中で、ハウテン州 (10.4\%)についで2番目に低かった (ibid.: 39)。

（10）本稿で引用した語りの［］内と下線部は引用者によるものである。

（11）正義和解協会の 2012 年の調査でも、「人種」カテゴリを巡る見解が割れている様子がう かがえる。例えば、政府は政策等の進渉を測るために「人種」カテゴリを使うべきである と考えているのは、全体の 49.2\%であるという結果が示された (Lefko-Everett 2012: 32)。 1996年と 2011 年の国勢調査を比べると、南アにおいて過去に抑圧されていた集団内の「教 
育格差」は減少傾向にあることが読み取れるが（Statistics South Africa 2012: 39）、「平等」を 測る際に使用される「人種」が認識のせめぎ合いの舞台となっているため、南アの「共 生」は、「人種」間の「格差」の是正という図式のみでは捉えきれそうにない。

\section{【引用文献】}

シリュルニク、ボリス (林昌宏訳)、2014、『憎むのでもなく、許すのでもなく一ユダヤ人一斉 検挙の夜』吉田書店。

羽田野真帆、2011、「聴覚障害児』の統合教育現場における共生」岡本智周・田中統治編

『共生と希望の教育学』筑波大学出版会、109-120頁。

井上達夫 ·名和田是彦・桂木隆夫、1992、「《人間が豊かな共生社会》をめざして」井上達夫 ·

名和田是彦・桂木隆夫編『共生への冒険』毎日新聞社、6-35頁。

ローレン、ポール・ゴードン (大蔵雄之助訳)、1995、『国家と人種偏見』TBS ブリタニカ。

峯陽一、1998、「南アフリカ新憲法の意義一『異端』から『縮図』へ」佐藤誠編『南アフリカ

の政治経済学一ポスト・マンデラとグローバライゼーション』明石書店、37-58頁。

野口道彦、2003、「都市共生社会学のすすめ」野口道彦・柏木宏編『共生社会の創造と NPO』

明石書店、17-45頁。

岡本智周、2013、『共生社会とナショナルヒストリー一歴史教科書の視点から』勁草書房。

大津和子、2000、「南アフリカにおける教育開発一ジェンダーの視点から」『国際教育協力論

集』、第3巻、第2号、97-114頁。

斎藤寛、1988、「せめぎあう共生一〈分けない＝くくらない〉ということ」岡村達雄編『教育 の現在 第二巻 現代の教育理論』社会評論社、331-363頁。

トンプソン、レナード (宮本正興・吉國恒雄・峯陽一・鶴見直城訳)、2009、『南アフリカの歴

史【最新版】(世界歴史叢書)』明石書店。

山本浩、1999、『真実と和解一ネルソン・マンデラ最後の闘い』NHK出版。

山田肖子、2005、「民主化と多文化共生一アフリカにおけるシチズンシップ教育への示唆」『国 際教育協力論集』、第8巻、第2号、75-87頁。

Bentley, Kristina \& Adam Habib, 2008, “ Racial Redress, National Identity and Citizenship in PostApartheid South Africa, ” Adam Habib \& Kristina Bentley eds., Racial Redress \& Citizenship in South Africa, HSRC (Human Sciences Research Council) Press, pp.3-32.

Department of Basic Education (DoBE) (The Republic of South Africa), 2011, Curriculum and Assessment Policy Statement Grade 10-12 Life Orientation.

Department of Education (DoE) (The Republic of South Africa), 2002, Policy Revised National Curriculum Statement Grades R-9 (Schools) Overview.

Department of Education (DoE) (The Republic of South Africa), 2003, National Curriculum Statement Grades 10-12 (General) Overview.

Lefko-Everett, Kate, 2012, Ticking Time Bomb or Demographic Dividend? Youth and Reconciliation in South Africa: SA Reconciliation Barometer Survey: 2012 Report, The Institute for Justice and Reconciliation.

Moodley, Kogila A., 2004, “ Challenges for Post-Apartheid South Africa: Decolonizing Education, " 
James A. Banks \& Cherry A. McGee Banks eds., Handbook of Research on Multicultural Education, 2nd ed., CA: Jossey-Bass, pp.1027-1040.

Prinsloo, Erna, 2007, "Implementation of Life Orientation Programmes in the New Curriculum in South African Schools: Perceptions of Principals and Life Orientation Teachers," South African Journal of Education, Vol.27, No.1, pp.155-170.

Statistics South Africa, 2012, Census 2011 Statistical Release (Revised).

Tihanyi, Krisztina Z, \& Stephanos F. Du Toit, 2005, “ Reconciliation Through Integration? An Examination of South Africa 's Reconciliation Process in Racially Integrating High Schools, ” Conflict Resolution Quarterly, Vol.23, Issue.1, pp.25-41.

Van Deventer, Karel, 2009, “ Perspectives of Teachers on the Implementation of Life Orientation in Grades R-11 from Selected Western Cape Schools," South African Journal of Education, Vol. 29, pp.127-145.

Volmink, John D., 2008, “Education for Learning to Live Together: What Can We Learn From the South African Experience?,” European Journal of Education, Vol.43, No.2, pp.189-196.

\section{【付記】}

本稿は、平成24-26年度日本学術振興会科学研究費補助金・特別研究員奨励費 (課題番 号 : $24 \cdot 766)$ の助成を受けたものである。 


\title{
Education for "Living Together" in the Republic of South Africa:
}

\section{Conflicts of Perceptions at High Schools in the Western Cape Province}

\author{
Masayasu SAKAGUCHI
}

(Graduate Student, University of Tsukuba / JSPS Research Fellow)

The purpose of this article is to consider conflicts of perceptions in education for "living together" in the Republic of South Africa (RSA) by analysing interview data which was collected at high schools in the province of the Western Cape.

Recently, various studies have been conducted to consider what it means for people to "live together" with others in society. One of the theories these studies suggest is that when considering the concept of "living together" (or the concept of a "living together society") as the concept which focuses on how to realise "social unity in diversity", it can only be thought of as a continuing process rather something which can actually be achieved. This is because when trying to respect the differences of people, the possibility of having conflicts in society becomes high; therefore, whenever conflicts arise, the concept of "living together" needs to be reformed. In this sense, the concept of "living together" can not only be seen as a "beautiful" or "harmonious" concept, but as an "unbeautiful" or "disharmonious" one due to the conflict in question. From current discussions on the concept of "living together", and when analysing education for "living together", this article focuses on how conflicts appear in the actual practice of "living together" and how they may be solved.

In order to enhance the validity of studies on the concept of "living together", it is necessary to consider as many contexts as possible. One such context can be seen in RSA, where the legacy of apartheid is being addressed in the various fields of society.

In post-apartheid RSA, it has been a challenge to overcome conflicts between different groups of people, particularly those based on tensions that emerged during the apartheid era. In other words, how victims and perpetrators of apartheid can "live together" has become one of the RSA's most important concerns in the post-apartheid era. Therefore various attempts have been made to resolve this issue, especially in the educational field.

Amongst all the educational reconstructions in post-apartheid RSA, the introduction of "Life Orientation" as a compulsory subject in the 2000 s can be said to be one of the most significant attempts at "living together". This is because Life Orientation is a new and unique subject in the RSA which deals 
with actual issues in society and aims to enable learners to know how to exercise their constitutional rights and responsibilities, to respect the rights of others, and to value diversity, health and well-being.

This article explains that Life Orientation at the high school phase in the RSA can be regarded as one of the most meaningful examples of education for "living together", because it tries to equip learners with skills that are necessary for realising the principles of the RSA Constitution - ones which emphasise anti-discrimination and social unity in diversity. In order to examine the characteristics of education for "living together" in the current RSA, this article focuses on educators' and learners' discourses related to Life Orientation when analysing interview data.

Interview data was collected at three high schools in the province of the Western Cape in 2012 and 2013. Participants were learners, Life Orientation educators and administrative educators (semistructured interviews were conducted in English). The aim of the interview was to reveal how education and learning for "living together" are taking place at high schools in the the current RSA by asking questions such as "What do you imagine when you hear the term "living together society?" and "What do you think is the key (or the obstacle) to [realising a] "living together society?"

This article discusses several results revealed by the above research. Firstly, it discusses a conflict of perception between those who believe that affirmative action is discrimination since it emphasises the category of "race", and those who believe that affirmative action is necessary in the current RSA given its legacy of apartheid. Secondly, this article discusses a conflict of perception between those who believe that discrimination in a "joking" way can be a positive thing since it may bring people closer, and those who believe that any form of discrimination should not be allowed since even "jokes" can hurt people. Thirdly, this article discusses that the reason why conflicts of perception exist is because there is an assumption that people's mind-sets should be tolerated and respected. Under this assumption, therefore, education does not focus mainly on changing the mind-sets of people but rather on educating learners the skills to be able to overcome the damage incurred from actual conflicts.

Finally, from the above analysis, this article narrows in on particular characteristics of education for "living together" in the current RSA. Firstly, it discusses that since the RSA has decided to build a new society with the victims and the perpetrators of apartheid, "living together" in the postapartheid era of the new RSA has consisted of conflicts between different kinds of people since its foundation. As such, this article discusses that because of the severe reality of the current RSA, education for "living together" at high school is conducted by not focusing on spreading the "beautiful" images of "living together" but on equipping learners with the skills to be able to "survive together" 
南アフリカ共和国における「共生」のための教育に関する一考察

with others in actual society. Secondly, this article discusses that although the effects from the past are diverse, social unity is trying to be achieved by sharing the perception that everyone in the RSA is influenced by the country's past. Thirdly, this article reinforces the theory of "living together" by pointing out that the current RSA's practices are built on the assumption that human beings make "mistakes". 